\title{
Succession and natural occurrence of saprobic fungi on leaves of Berchemia floribunda (climber) and their association with Magnolia liliifera (host)
}

\author{
Promputtha $I^{1,2 *}$ McKenzie $\mathrm{EHC}^{3}$, Tennakoon $\mathrm{DS}^{4,5,6}$, Lumyong $\mathrm{S}^{1}$ and \\ Hyde KD ${ }^{1,4,5,6}$
}

${ }^{1}$ Department of Biology, Faculty of Science, Chiang Mai University, Chiang Mai, 50200, Thailand

${ }^{2}$ Center of Excellence in Bioresources for Agriculture, Industry and Medicine, Department of Biology, Faculty of Science, Chiang Mai University, Thailand

${ }^{3}$ Manaaki Whenua Landcare Research, Private Bag 92170, Auckland, New Zealand

${ }^{4}$ Center of Excellence in Fungal Research, Mae Fah Luang University, Chiang Rai, 57100, Thailand

${ }^{5}$ School of Science, Mae Fah Luang University, Chiang Rai, 57100, Thailand

${ }^{6}$ World Agro Forestry Centre, East and Central Asia, 132 Lanhei Road, Kunming 650201, Yunnan China

Promputtha I, McKenzie EHC, Tennakoon DS, Lumyong S, Hyde KD 2019 - Succession and natural occurrence of saprobic fungi on leaves of Berchemia floribunda (climber) and their association with Magnolia liliifera (host). Mycosphere 10(1), 1100-1114, Doi 10.5943/mycosphere/10/1/21

\begin{abstract}
Fungal succession on various plants from different regions of the world have been wellstudied, however there has been no report comparing the fungi on leaves of a climber with those of the supportive plant. Fungi on leaves of Berchemia floribunda, a climber, were studied to fungal diversity and succession over a period of leaf decomposition. These fungi were compared with those on leaves of Magnolia liliifera, the supportive plant, using data from previous studies at the same site. Leaves of $B$. floribunda were placed with the upper or lower leaf surface adjacent to the forest floor, hung above the ground either under the host tree or other tree species, or placed on the forest floor under the host tree or under other trees to establish the effects of these treatments. These leaf bait trials did not affect the fungal diversity on the leaves. There was very little overlap between fungi on the climber leaves and those on the support tree. Only four saprobes from $B$. floribunda were also found on leaves of M. liliifera. We suspect that most of the fungi degrading leaves of $B$. floribunda were initially endophytes and became active saprobes once leaves started to decay.
\end{abstract}

Key words - Fungal diversity - Fungal ecology - Fungal succession - Leaf decomposition Percentage occurrence

\section{Introduction}

Fungal succession has been observed in both terrestrial and aquatic ecosystems of tropical and temperate regions (Ho et al. 2002, Somrithipol et al. 2002, Suzuki et al. 2002, Yanna et al. 2002, Handa \& Harada 2005, Tang et al. 2005, Paulus et al. 2006, Kodsueb et al. 2015, Matsuoka et al. 2018, Gao et al. 2019, Herzog et al. 2019). Most studies focused on the change in composition of fungal communities with changes of plant species, following different types of disturbances, 
such as animal, fire, land slide and deforestation (McMullan-Fisher et al. 2002, Suzuki et al. 2002, Zhang et al. 2017, Shi et al. 2019). There have been numerous studies of fungal succession on a variety of substrata, for instance cellulose film (Tribe 1957, 1961), other cellulosic substrates (Gorska 1982), plant litter (Promputtha et al. 2002, 2017, Tokumasu \& Aoiki 2002, Yanna et al. 2002, Zhou \& Hyde 2002, Handa \& Harada 2005, Paulus et al. 2006, Voř́šková \& Baldrian 2013), and wool (Ghawana et al. 1997).

Previous studies have also investigated fungal succession on various plant species from different regions of the world (Frankland 1966, Richardson 2002, Sivichai et al. 2002, Somrithipol et al. 2002, Suzuki et al. 2002, Tokumasu \& Aoiki 2002, Yanna et al. 2002, Zhou \& Hyde 2002, Paulus et al. 2006, Voříšková \& Baldrian 2013, Promputtha et al. 2017), but there has been no report comparing the fungi on leaves of a climber with those of the supportive plant. There have been few studies on fungal succession in Thailand, a tropical region (Kodsueb et al. 2015, Promputtha et al. 2017). Somrithipol et al. (2002) investigated succession of fungi on fruits and seeds of Delonix regia exposed on the forest floor. Sivichai et al. (2002) studied fungal colonization on two timbers, Dipterocarpus alatus and Xylia dolabriformis, exposed in a fresh water stream. Promputtha et al. (2002) investigated fungal succession on senescent leaves of Manglietia garrettii (later corrected to Magnolia liliifera) and found that the upper or lower leaf surface facing the forest floor had no effect on fungal communities developing on leaves.

In this study, leaves of Berchemia floribunda (a woody climber) in Doi Suthep-Pui National Park, Thailand were studied. The objectives were to evaluate fungal diversity, examine the succession of fungi over the period of leaf decomposition and determine the effect of various leaf placements on fungal diversity.

\section{Materials \& Methods}

Two-hundred and fifty senescent leaves of Berchemia floribunda were collected from Doi Suthep-Pui National Park, Chiang Mai, Thailand in June (wet season). Selected senescent leaves were recently fallen and had yellow-green with fresh abscission scars. Ten of the senescent leaves were randomly selected to represent day 0 . Bright-coloured wool was tied to the petioles of the other 240 senescent leaves to mark the samples. The leaves were randomly placed under $B$. floribunda and $M$. liliifera trees with one of the following treatments or control. In treatment 1, 50 leaves were hung under B. floribunda; in treatment 2, 50 leaves were placed on the forest floor under B. floribunda; in treatment 3, 50 leaves were hung under M. liliifera trees; and in treatment 4, 50 leaves were placed on the forest floor under M. liliifera trees. The control treatment comprised 40 senescent leaves tied with different coloured bright wool. These leaves were autoclaved twice at $121^{\circ} \mathrm{C}$ for 15 minutes and then returned to the forest. Ten of the sterilized leaves were hung under B. floribunda; 10 were placed on the forest floor under $B$. floribunda; 10 were hung under $M$. liliifera trees; and 10 were placed on the forest floor under M. liliifera trees (Fig. 1).

At each sampling time, five marked leaves from each treatment were collected. Marked leaves were collected at days 4, 8, 16, 24, 32, 40, 48, 56, 64 and 72. However at day 24, leaves were almost decayed and highly skeletonized comprising vascular tissue with attached remnants of inter-vein tissue. Sterilized leaves were collected at day 16, before complete decay (summarized experimental design of the trial is showed in Fig. 1). Samples were placed in separate plastic bags in the forest and taken back to the laboratory. Samples were incubated individually in plastic bags with the addition of sterile tissue paper moistened with sterile water. Samples collected at day 0 were examined for the presence of fungi on the day the experiment was set up. All other samples were examined using a microscope for the presence of fungi after one day of incubation. Sporulating fungi were mounted in water on glass slides and examined using differential interference contrast microscopy. Fungi were isolated by single spore isolation techniques (Chomnunti et al. 2014). Herbarium specimens of fungi were prepared and air-dried in an oven at $37^{\circ} \mathrm{C}$ for one week.

During the examination period, 50 naturally fallen decaying leaves of $B$. floribunda at various stages of decay were collected and examined immediately for comparison of fungal communities 
with those from the succession study.

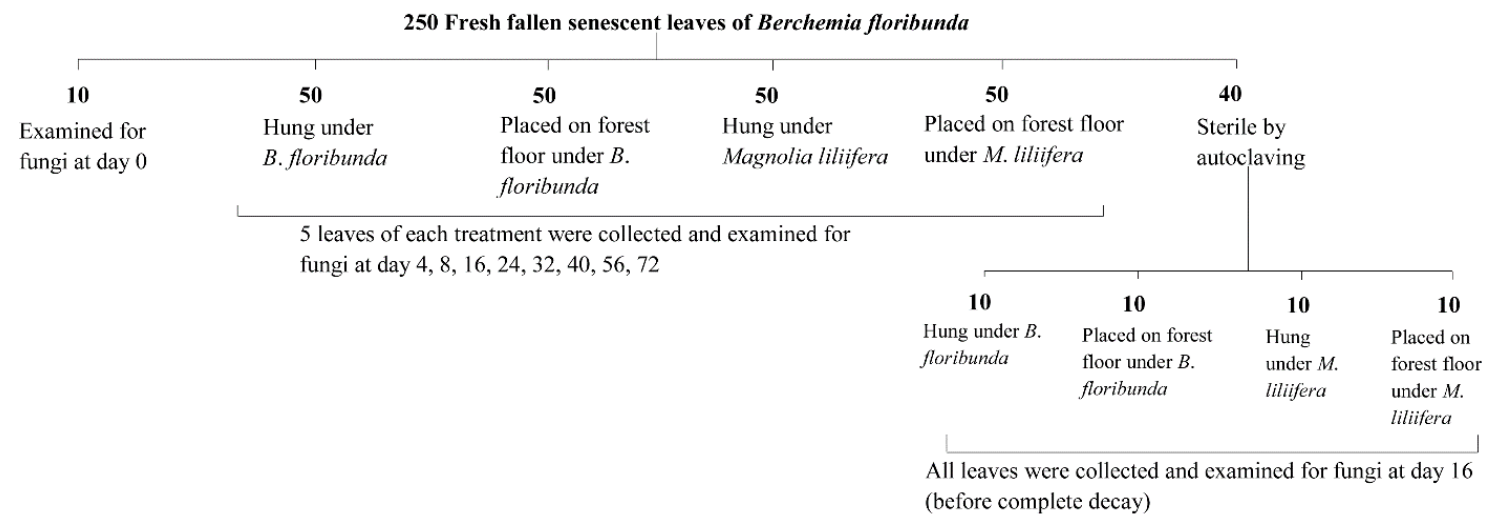

Figure 1 - Experimental design of leaf bait trials for fungal diversity investigation throughout decomposition period of Berchemia floribunda leaves. Statistical analyses and samples calculation are given in Promputtha et al. (2017).

\section{Results}

\section{Fungi on naturally decaying leaves}

Fungal taxa recorded on 50 naturally decaying leaves of $B$. floribunda, with their percentage occurrence, are listed in Table 1. Of the 40 fungal taxa identified, 32 species were found during the succession study and the eight different species were: Berkleasmium phyllostachydis, Cladosporium oxysporum, Dictyosporium sacchari, Helicomyces sp., Lasiodiplodia theobromae, Nectria sp. 2, Periconia lateralis, and Verticillium sp. 2. The dominant species were Mycosphaerella sp. 2 (100\%), Dictyochaeta tropicalis (84\%), Beltrania rhombica (74\%), Cylindrocladium floridanum (64\%), Volutella sp. 2 (64\%), and an unidentified ascomycete 1 $(58 \%)$.

Table 1 Percentage occurrence of fungi found on 50 naturally decaying leaves of Berchemia floribunda.

\begin{tabular}{lcc}
\hline \multicolumn{1}{c}{ Fungus } & Number of leaves & Percentage occurrence \\
\hline Mycosphaerella sp. 2 & 50 & 100 \\
Dictyochaeta tropicalis & 42 & 84 \\
Beltrania rhombica & 37 & 74 \\
Cylindrocladium floridanum & 32 & 64 \\
Volutella sp. 2 & 32 & 64 \\
Unidentified ascomycete 1 & 29 & 58 \\
Volutella sp. 3 & 26 & 52 \\
Bacillispora sp. & 24 & 48 \\
Colletotrichum sp. 1 & 24 & 48 \\
Dactylaria sp. 6 & 24 & 48 \\
Ellisiopsis gallesiae & 24 & 48 \\
Colletotrichum sp. 2 & 23 & 46 \\
Colletotrichum sp. 5 & 21 & 42 \\
Beltraniopsis eusenbeckiae & 20 & 40 \\
Circinotrichum flexuosum & 16 & 32 \\
Colletotrichum sp. 3 & 15 & 30 \\
\hline
\end{tabular}


Table 1 Continued.

\begin{tabular}{lcc}
\hline \multicolumn{1}{c}{ Fungus } & Number of leaves & Percentage occurrence \\
\hline Periconia byssoides & 15 & 30 \\
Wiesneriomyces javanicus & 14 & 28 \\
Colletotrichum sp. 4 & 12 & 24 \\
Cylindrocladium infestans & 8 & 16 \\
Dactylaria sp. 7 & 8 & 16 \\
Idriella sp. 2 & 8 & 16 \\
Dactylaria sp. 8 & 7 & 14 \\
Acremonium sp. & 6 & 12 \\
Pithomyces chartarum & 6 & 12 \\
Cladosporium oxysporum & 5 & 10 \\
Verticillium sp. 1 & 5 & 10 \\
Dictyochaeta cocophilum & 4 & 8 \\
Pestalotiopsis sp. & 4 & 8 \\
Diplodia theobromae & 3 & 6 \\
Stachybotrys sp. & 3 & 6 \\
Berkleasmium phyllostachydis & 2 & 4 \\
Cylindrocladium lucidum & 2 & 4 \\
Dictyosporium sacchari & 2 & 4 \\
Lasiodiplodia theobromae & 2 & 4 \\
Periconia lateralis & 2 & 4 \\
Helicomyces sp. & 1 & 2 \\
Memnoniella levispora & 1 & 2 \\
Nectria sp. 2 & 1 & 2 \\
Verticillium sp. 2 & 1 & 2 \\
\hline
\end{tabular}

\section{Fungi on leaf bait treatments}

Forty fungal taxa were identified on leaves of Berchemia floribunda throughout 24 days of the study (Table 2). These results are separated into those fungi on leaves either hung under $B$. floribunda plants or placed on the forest floor under B. floribunda plants, and those hung under $M$. liliifera trees or placed on the forest floor under M. liliifera trees. Thirty-two taxa were identified on leaves hung under B. floribunda, 33 on leaves placed on the forest floor under B. floribunda, 27 on leaves hung under M. liliifera, and 28 on leaves placed on the forest floor under M. liliifera. The overall dominant species were Dictyochaeta tropicalis (45\%), Mycosphaerella sp. 2 (43\%), Colletotrichum sp. 1 (34\%), Bacillispora sp. (28\%), and Beltrania rhombica (27\%).

\section{Effect of leaf bait treatments on fungal communities}

Thirty-two taxa were found on leaves hung under B. floribunda plants. The dominant species were Mycosphaerella sp. 2 (64\%), Colletotrichum sp. 1 (40\%), Dictyochaeta tropicalis (32\%), Bacillispora sp. (28\%), and Colletotrichum sp. 5 (28\%) (Fig. 3). Thirty-three fungal taxa were found on leaves placed on the forest floor under $B$. floribunda plants. The dominant species were Dictyochaeta tropicalis (60\%), Mycosphaerella sp. 2 (48\%), Colletotrichum sp. 1 (44\%), Colletotrichum sp. 2 (32\%), Beltrania rhombica (32\%), and Beltraniopsis esenbeckiae (32\%) (Fig. 4).

Twenty-seven fungal taxa were found on leaves hung under $M$. liliifera trees. The dominant species were Dictyochaeta tropicalis (32\%), Colletotrichum sp. 2 (28\%), Bacillispora sp. (28\%), Colletotrichum sp. 1 (24\%), Mycosphaerella sp. 2 (24\%), and Beltrania rhombica (24\%) (Fig. 5). Twenty-eight fungal taxa were found on leaves placed on the forest floor under M. liliifera trees. 
The dominant species were Dictyochaeta tropicalis (56\%), Mycosphaerella sp. 2 (36\%), Beltrania rhombica (36\%), Bacillispora sp. (32\%), and Ellisiopsis gallesiae (32\%) (Fig. 6).

Three-dimensional correspondence analysis of fungal communities on decaying leaves of $B$. floribunda showed that the bait treatment of leaves had no effect on colonization of saprobic fungi on B. floribunda (Fig. 2). The fungal communities on leaves hung or placed on the forest floor under $B$. floribunda were similar to those hung or placed on the forest floor under M. liliifera in both species diversity and occurrence.

Table 2 Number of leaves of Berchemia floribunda on which fungus occurred during the succession process.

\begin{tabular}{|c|c|c|c|c|c|c|c|c|c|c|c|c|c|c|c|c|c|c|c|c|c|c|c|c|c|}
\hline \multirow{3}{*}{ Fungus } & \multicolumn{6}{|c|}{ HB } & \multirow{2}{*}{\multicolumn{5}{|c|}{ FB }} & \multicolumn{7}{|c|}{ HM } & \multicolumn{6}{|c|}{ FM } & \multirow{3}{*}{ Overall \% } \\
\hline & \multicolumn{5}{|c|}{ Day } & \multirow{2}{*}{$\%$} & & & & & & \multirow{2}{*}{$\%$} & \multicolumn{5}{|c|}{ Day } & \multirow{2}{*}{$\%$} & \multicolumn{5}{|c|}{ Day } & \multirow{2}{*}{$\%$} & \\
\hline & $\mathbf{0}$ & 4 & 8 & 16 & 24 & & $\mathbf{0}$ & 4 & 8 & 16 & 24 & & $\mathbf{0}$ & 4 & 8 & 16 & 24 & & $\mathbf{0}$ & 4 & 8 & 16 & 24 & & \\
\hline Colletotrichum sp. 1 & 1 & 3 & 5 & 1 & & 40 & 1 & 5 & 5 & & & 44 & 1 & 2 & 3 & & & 24 & 1 & 1 & 4 & 1 & & 28 & 34 \\
\hline Colletotrichum sp. 2 & 1 & 1 & 2 & & & 16 & 1 & 3 & 4 & & & 32 & 2 & 1 & 3 & 1 & & 28 & 1 & 1 & 3 & & & 16 & 23 \\
\hline Mycosphaerella sp. 2 & 1 & 4 & 5 & 5 & 1 & 64 & 1 & 3 & 5 & 1 & 2 & 48 & 2 & 1 & 0 & 1 & 2 & 24 & 1 & 3 & 1 & 2 & 2 & 36 & 43 \\
\hline Bacillispora sp. & & 1 & 0 & 5 & 1 & 28 & & & 2 & 2 & 2 & 24 & & 1 & 1 & 3 & 2 & 28 & & 2 & 2 & 3 & 1 & 32 & 28 \\
\hline Beltrania rhombica & & 1 & 1 & 1 & 1 & 16 & & 1 & 3 & 1 & 3 & 32 & & 1 & 3 & 2 & & 24 & & 1 & 2 & 2 & 4 & 36 & 27 \\
\hline Beltraniopsis esenbeckiae & & 1 & 1 & 2 & 1 & 20 & & 1 & 3 & 1 & 3 & 32 & & 1 & 1 & 2 & 1 & 20 & & 1 & 2 & 2 & 2 & 28 & 25 \\
\hline Colletotrichum sp. 3 & & 1 & 2 & & & 12 & & 3 & 4 & & & 28 & & 1 & 1 & & & 8 & & 3 & 2 & 1 & & 24 & 16 \\
\hline Colletotrichum sp. 4 & & 1 & 1 & & & 8 & & 1 & 2 & & & 12 & & 1 & & & & 4 & & 1 & 2 & & & 12 & 9 \\
\hline Colletotrichum sp. 5 & & 1 & 1 & 4 & 1 & 28 & & 1 & 5 & & & 24 & & & 1 & 3 & 1 & 20 & & 1 & 2 & 2 & 1 & 24 & 24 \\
\hline Cylindrocladium floridanum & & 1 & 3 & 1 & & 20 & & 2 & 1 & & & 12 & & 2 & 2 & 1 & & 20 & & 1 & 2 & 1 & & 16 & 17 \\
\hline Cylindrocladium infestans & & & & & & 0 & & 1 & 1 & & & 8 & & & 1 & & & 4 & & 1 & 1 & & & 8 & 5 \\
\hline Cylindrocladium lucidum & & & & & & 0 & & 1 & & & & 4 & & & & & & 0 & & & & & & 0 & 1 \\
\hline Dactylaria sp. 6 & & 1 & 0 & 4 & & 20 & & 1 & 2 & 3 & & 24 & & 1 & 1 & & & 8 & & 1 & 2 & 1 & & 16 & 17 \\
\hline Dictyochaeta tropicalis & & 3 & 4 & 0 & 1 & 32 & & 1 & 5 & 5 & 4 & 60 & & 2 & 2 & 3 & 1 & 32 & & 2 & 4 & 5 & 3 & 56 & 45 \\
\hline Ellisiopsis gallesiae & & 1 & 1 & 1 & & 12 & & 1 & 3 & 2 & & 24 & & 1 & 1 & 2 & & 16 & & 1 & 4 & 2 & 1 & 32 & 21 \\
\hline Idriella sp. 2 & & 1 & 0 & 3 & 1 & 20 & & & 1 & & & 4 & & & 1 & & & 4 & & & & & & 0 & 7 \\
\hline Memnoniella levispora & & 1 & & & & 4 & & & & & & 0 & & & & & & 0 & & & & & & 0 & 1 \\
\hline Periconia byssoides & & 1 & 0 & 4 & & 20 & & 1 & 3 & 1 & & 20 & & 1 & 2 & 1 & & 16 & & & 1 & 1 & & 8 & 16 \\
\hline
\end{tabular}


Table 2 Continued.

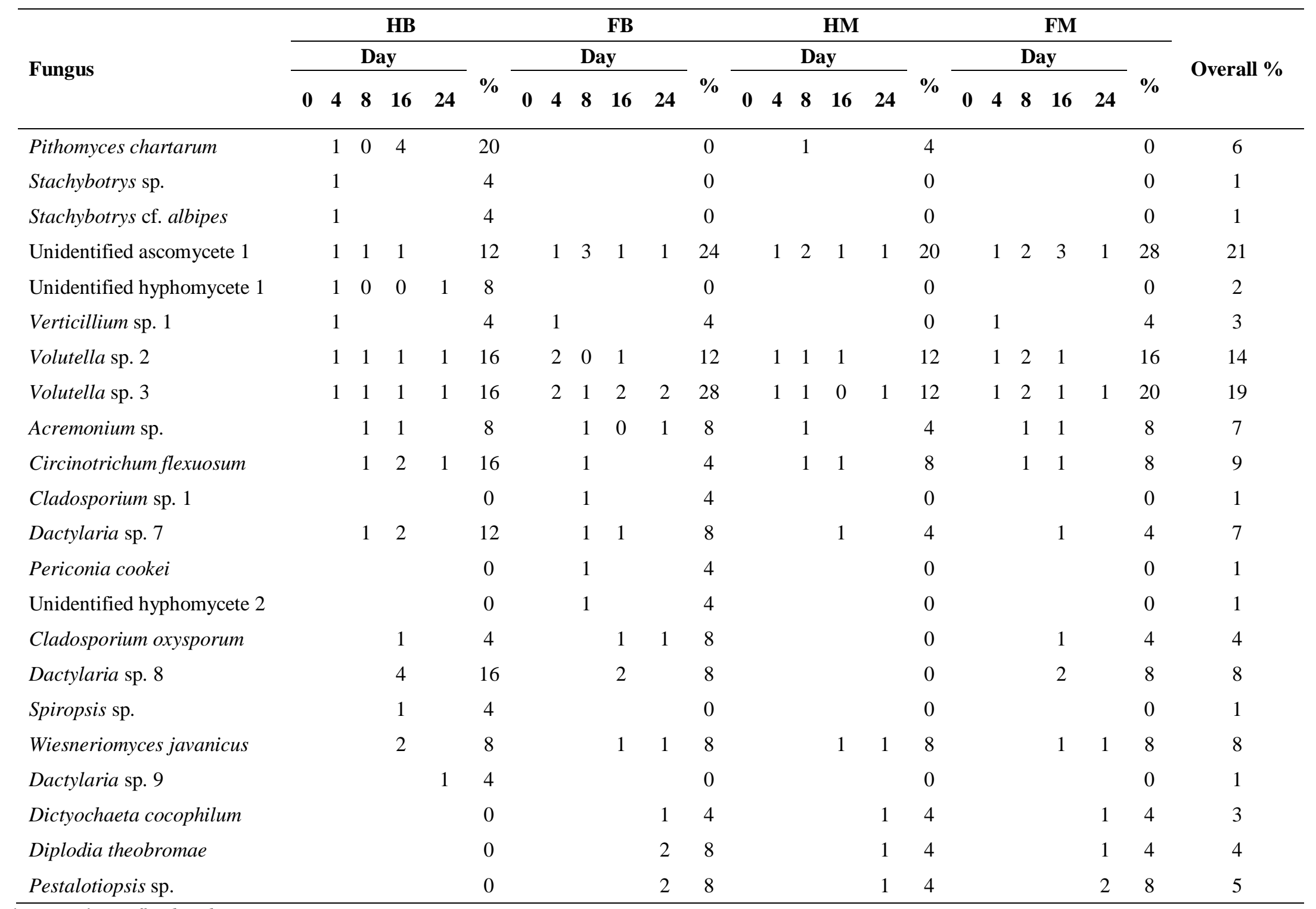

HB: Leaves hung under B. floribunda tree 
FB: Leaves placed on forest floor under B. floribunda

HM: Leaves hung under M. liliifera

FM: Leaves placed on forest floor under M. liliifera

\section{Fungal colonization on sterilized leaves}

Fourteen fungal taxa were found on 40 sterilized leaves of $B$. floribunda (control group), collected at day 16 of decomposition (Table 3). All of these fungi were the same species as those found on non-sterilized leaves and colonized as dominant species. Dominant species on nonsterilized leaves, which were absent from sterilized leaves were Colletotrichum spp. 1, 2, 3, 5, Bacillispora sp., Dactylaria sp. 6, and unidentified ascomycete 1.

Table 3 Percentage occurrence of fungi found on sterilized leaves (control group) of Berchemia floribunda, ten leaves in each group.

\begin{tabular}{|c|c|c|c|c|c|}
\hline \multirow{2}{*}{ Fungal taxa } & \multicolumn{4}{|c|}{ Percentage occurrence } & \multirow{2}{*}{$\begin{array}{c}\text { Overall percentage } \\
\text { occurrence }\end{array}$} \\
\hline & HB & FB & HM & FM & \\
\hline Beltrania rhombica & 100 & 100 & 80 & 100 & 95 \\
\hline Beltraniopsis esenbeckiae & 60 & 50 & 70 & 70 & 62.5 \\
\hline Cylindrocladium floridanum & 90 & 100 & 70 & 100 & 90 \\
\hline Cylindrocladium infestans & 40 & 30 & 50 & 40 & 40 \\
\hline Dactylaria sp. 7 & 10 & & & & 2.5 \\
\hline Dictyochaeta tropicalis & 100 & 100 & 100 & 100 & 100 \\
\hline Diplodia theobromae & 20 & 10 & & 10 & 10 \\
\hline Ellisiopsis gallesiae & 100 & 100 & 100 & 100 & 100 \\
\hline Mycosphaerella sp. 2 & 10 & & & & 2.5 \\
\hline Periconia byssoides & & & 10 & & 2.5 \\
\hline Pithomyces chartarum & 20 & 10 & & & 7.5 \\
\hline Pestalotiopsis sp. & 40 & 20 & 30 & 40 & 32.5 \\
\hline Volutella sp. 3 & & & 10 & & 2.5 \\
\hline Volutella sp. 2 & & 10 & & & 2.5 \\
\hline
\end{tabular}

HB: Leaves hung under B. floribunda

FB: Leaves placed on forest floor under B. floribunda

HM: Leaves hung under Magnolia liliifera

FM: Leaves placed on forest floor under M. liliifera

\section{Succession patterns of fungi on senescence leaves of Berchemia floribunda}

There were three distinct succession communities on decaying leaves of Berchemia floribunda over 24 days of decomposition; the pioneer community (day 0-4), the mature community (day 8-16), and the impoverished community (day 24 onwards) (Fig. 3). The fungal community composition was distinct at each stage of succession. During the pioneer community stage, fungal communities were low in number of species and the species also had a low percentage occurrence. The dominant species at this stage were Colletotrichum sp. 1, Colletotrichum sp. 2, and Mycosphaerella sp. 2. The highest species diversity was present during the mature community stage and they also had high percentage occurrence. The dominant species were Bacillispora sp., Beltrania rhombica, Colletotrichum sp. 3, Colletotrichum sp. 5, Cylindrocladium floridanum, Dactylaria sp. 6, Dictyochaeta tropicalis, Ellisiopsis gallesiae, Periconia byssoides, unidentified ascomycete 1, Volutella sp. 2, and Volutella sp. 3. In the impoverished community stage, the species diversity and number of species decreased. Species from earlier stages of decomposition persisted through this stage, but at low frequency. 


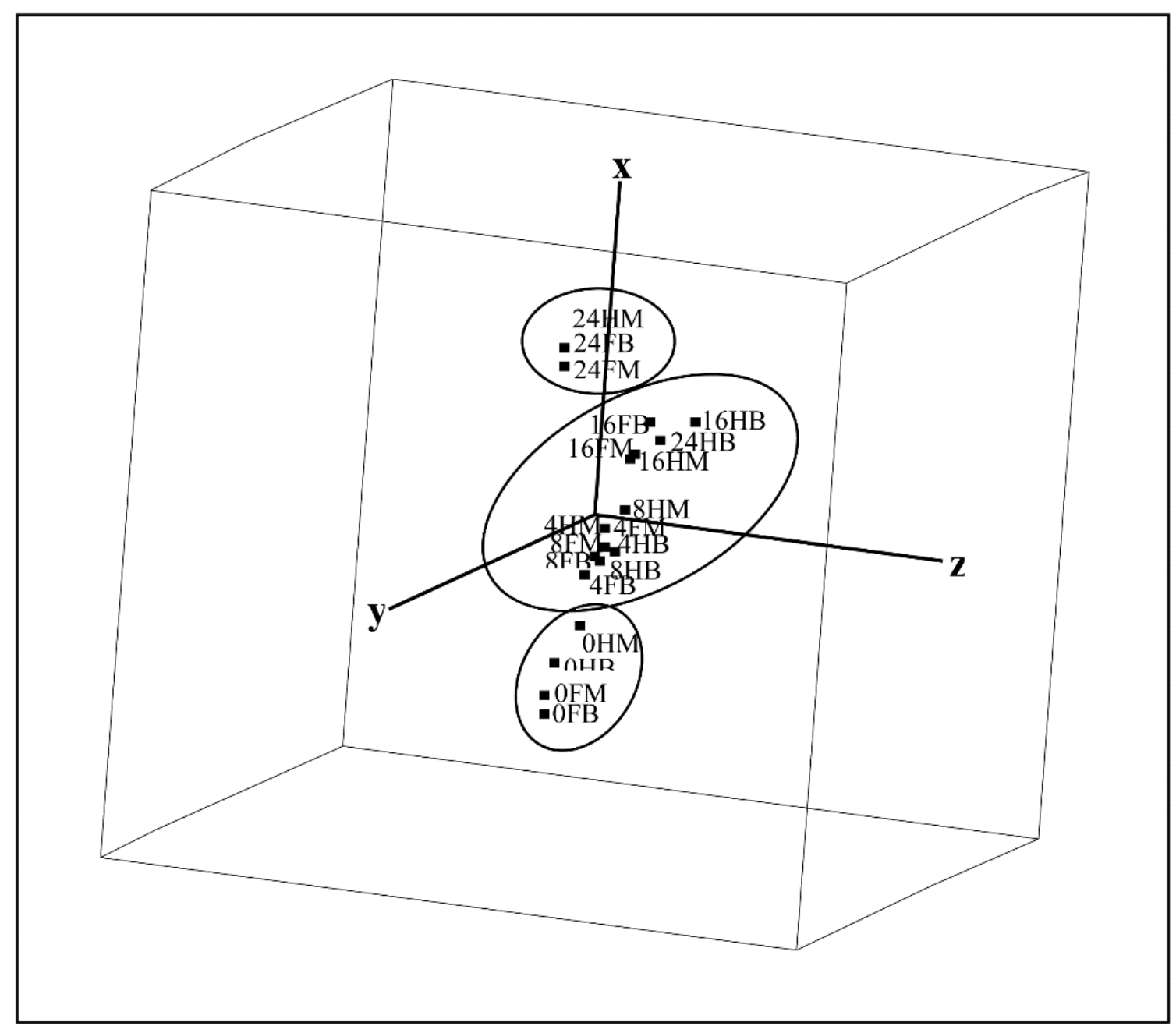

Figure 2 - Three-dimensional correspondence analysis of fungal communities on leaves of $B$. floribunda either hung under B. floribunda trees (HB) or placed on forest floor under $B$. floribunda trees (FB), and those hung under M. liliifera trees (HM) or placed on forest floor under M. liliifera trees (FM) over a 24 day period. 0, 4, 8, 16, 24 sampling times (days).

\section{Discussion}

\section{Fungal succession}

There have been several studies of the fungal succession on various materials, including submerged wood in fresh water (Ho et al. 2002, Kane et al. 2002, Sivichai et al. 2002, Newman et al. 2015, Matsuoka et al. 2018), leaf litter (Osono 2002, Promputtha et al. 2002, 2017, Yanna et al. 2002), pods of Dolenix regia (Somrithipol et al. 2002) and dung (Richardson 2001, 2002). Numerous studies have established similar patterns in fungal occurrence with time during fungal succession, there being early, intermediate and late colonizers (Jones \& Hyde 2002). Changes of species composition throughout the decay process have been observed and classified by several authors (Dix \& Webster 1985, Promputtha et al. 2002, 2017, Yanna et al. 2002, Zhou \& Hyde 2002). In the present study, the fungal communities grouped into three succession stages, the pioneer stage, mature stage and impoverished stage (Dix \& Webster 1985, Promputtha et al. 2002, 2017, Yanna et al. 2002, Voř́ššková \& Baldrian 2013). Leung (1998) divided fungi from bamboo into two groups, early colonizers and regular inhabitants, while Zhou \& Hyde (2002) divided fungi identified on bamboo into five groups, early colonizers, middle stage colonizers, later colonizers, regular inhabitants and sporadic inhabitants. 


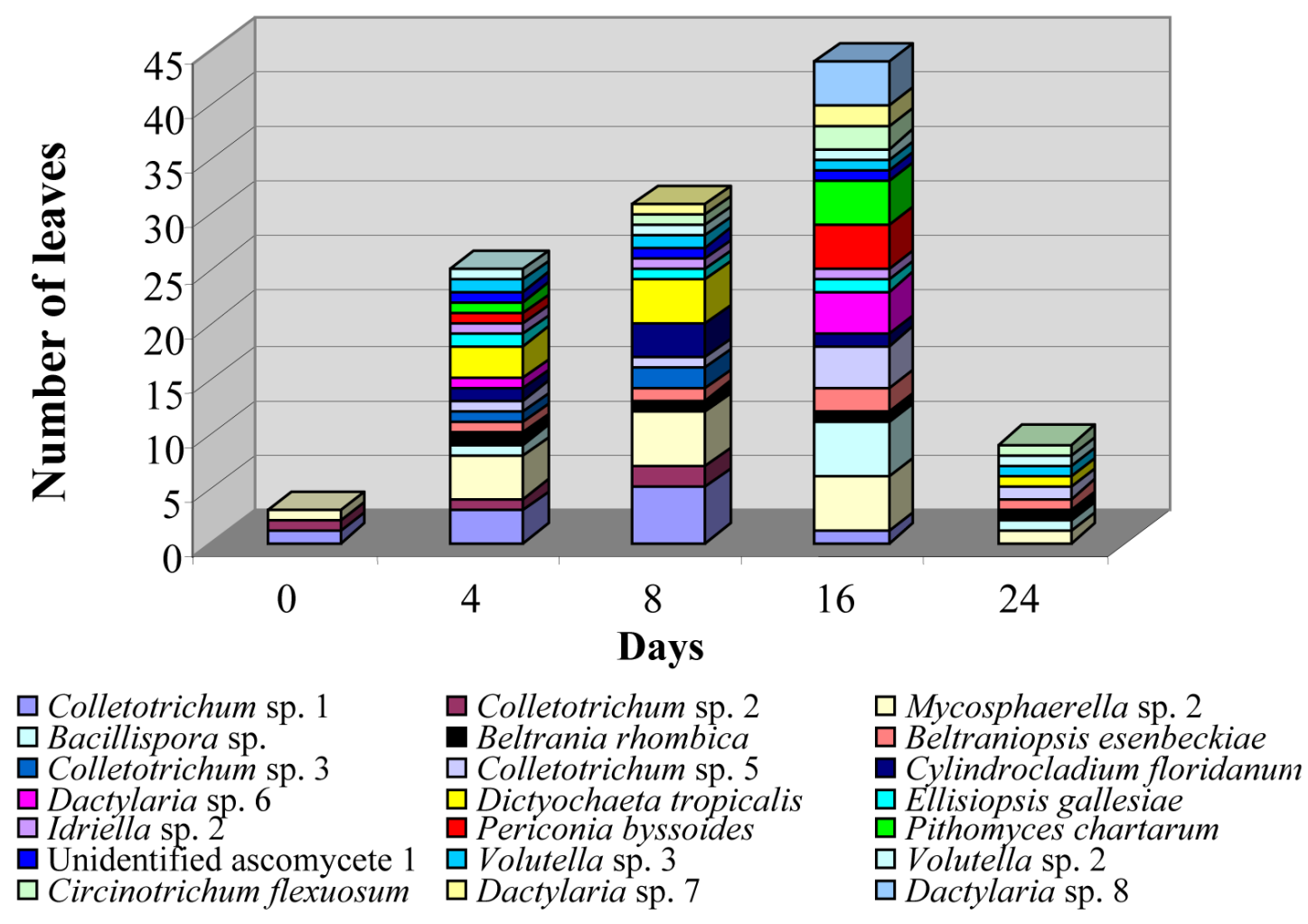

Figure 3 - Succession pattern of dominant fungi on leaves of Berchemia floribunda hung under $B$. floribunda plants during a 24 day period.
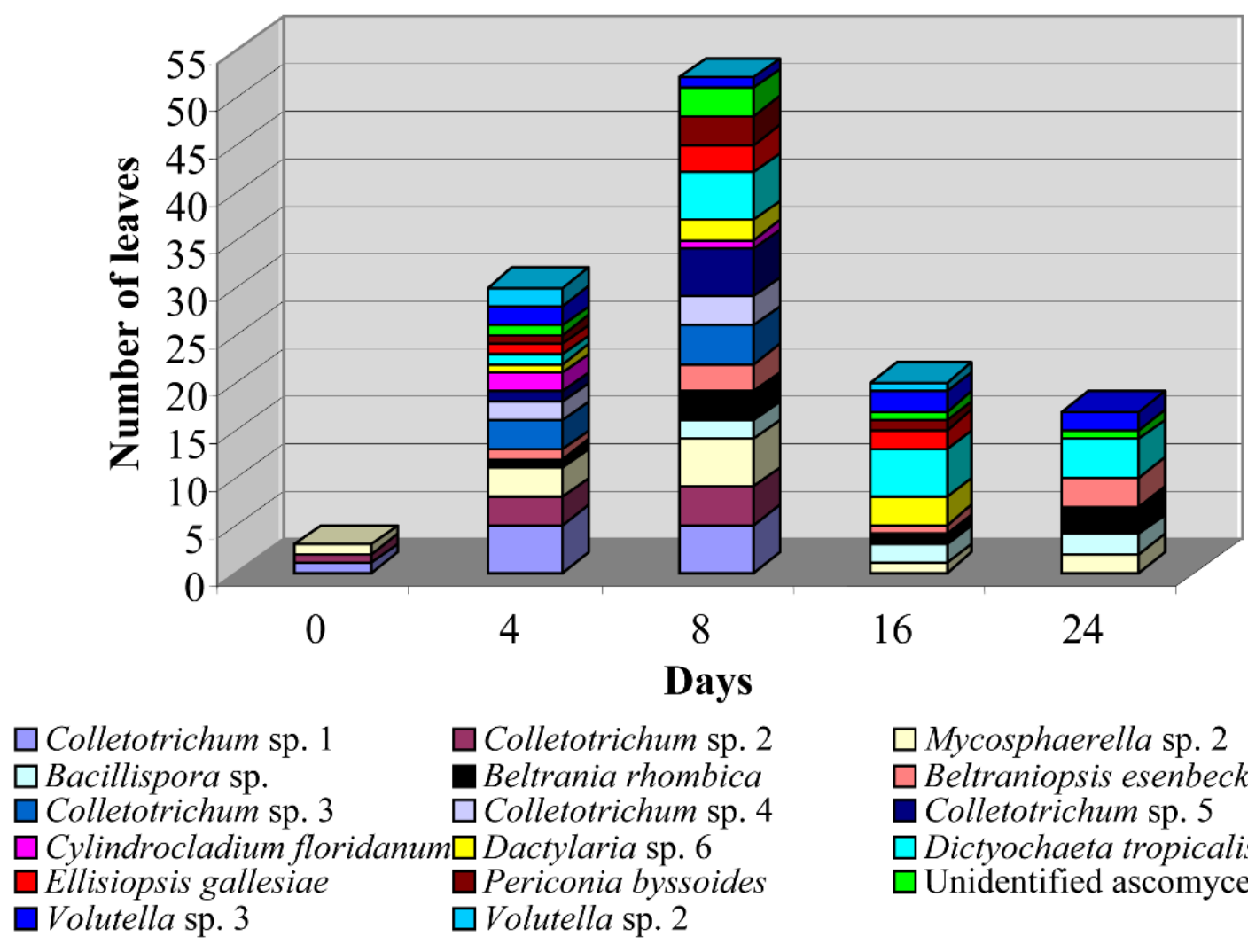

$\square$ Mycosphaerella sp. 2

$\square$ Beltraniopsis esenbeckiae

- Colletotrichum sp. 5

$\square$ Dictyochaeta tropicalis

$\square$ Unidentified ascomycete 1

Volutella sp. 3 Volutella sp. 2

Figure 4 - Succession pattern of dominant fungi on leaves of Berchemia floribunda placed on forest floor under B. floribunda plants during a 24 day period. 


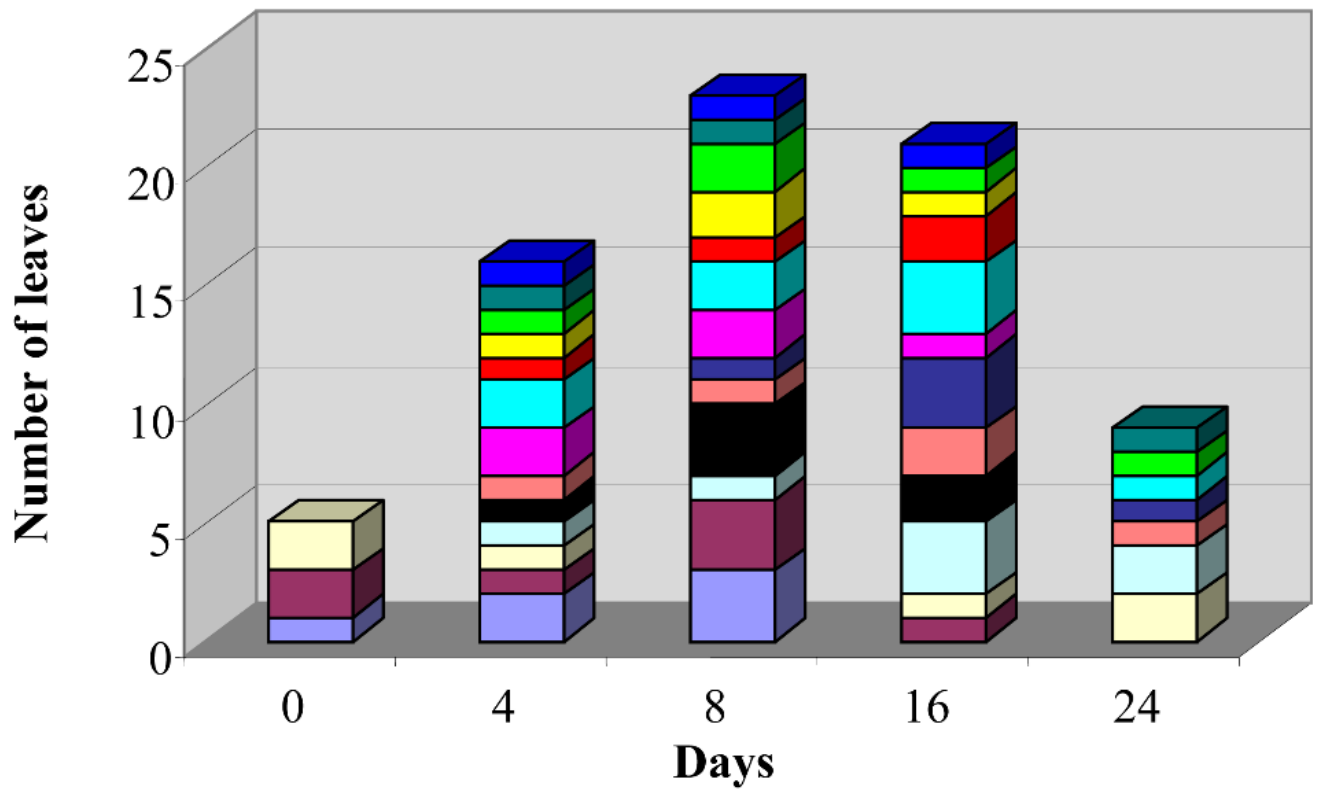

Colletotrichum sp. 1

$\square$ Bacillispora sp.

$\square$ Colletotrichum sp. 5

$\square$ Ellisiopsis gallesiae

$\square$ Volutella sp. 3
Colletotrichum sp. 2

- Beltrania rhombica

$\square$ Cylindrocladium floridanum

$\square$ Periconia byssoides

Volutella sp. 2 $\square$ Mycosphaerella sp. 2

$\square$ Beltraniopsis esenbeckiae

$\square$ Dictyochaeta tropicalis

$\square$ Unidentified ascomycete 1

Figure 5 - Succession pattern of dominant fungi on leaves of Berchemia floribunda hung under Magnolia liliifera tree during a 24 day period.

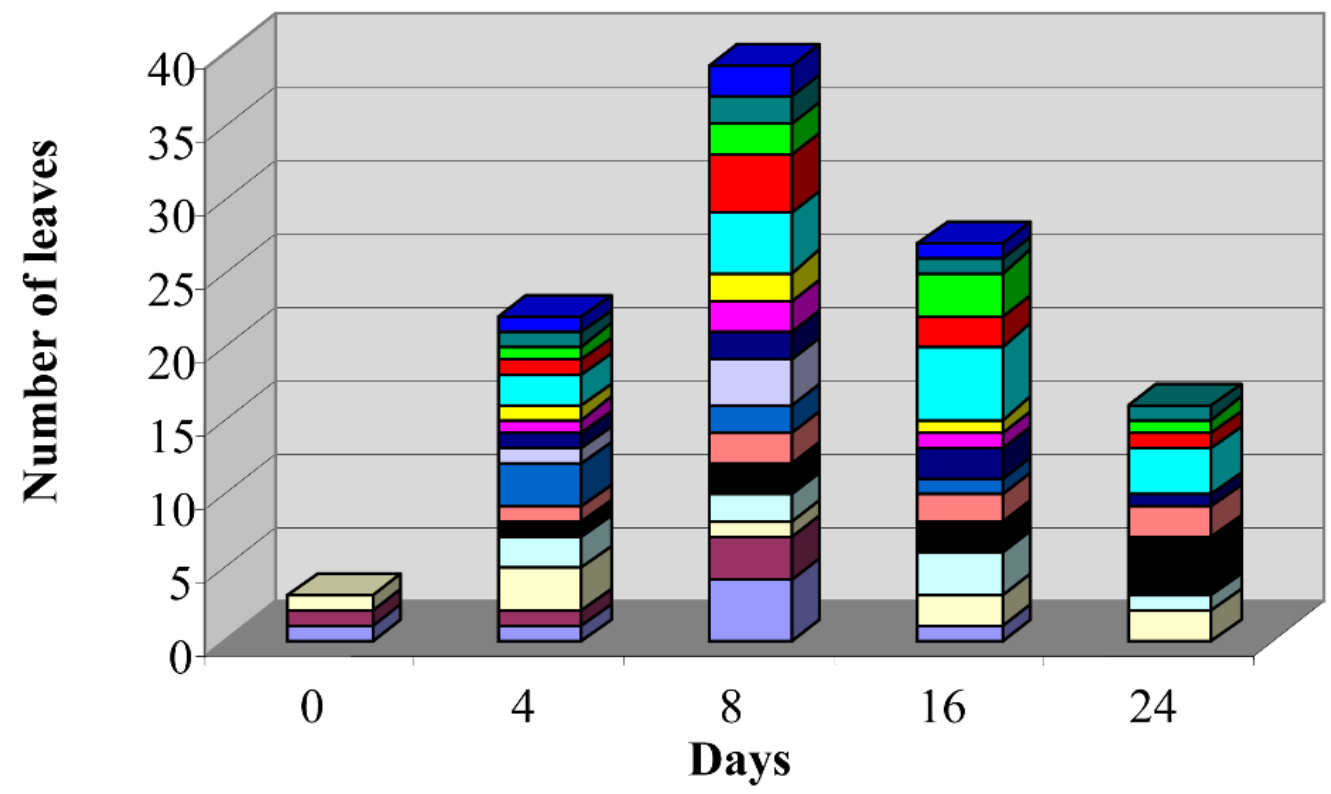

$\square$ Colletotrichum sp. 1

$\square$ Bacillispora sp.

Colletotrichum sp. 3

Cylindrocladium floridanum

$\square$ Ellisiopsis gallesiae

Volutella sp. 2 $\square$ Colletotrichum sp. 2

Beltrania rhombica $\square$ Colletotrichum sp. 4

$\square$ Dactylaria sp. 6

口Unidentified ascomycete 1
Mycosphaerella sp. 2

$\square$ Beltraniopsis esenbeckiae

Colletotrichum sp. 5

$\square$ Dictyochaeta tropicalis

$\square$ Volutella sp. 3

Figure 6 - Succession pattern of dominant fungi on leaves of Berchemia floribunda placed on forest floor under Magnolia liliifera tree during a 24 day period. 


\section{Fungal diversity}

The fungal communities on leaves of Berchemia floribunda during the succession period grouped into three stages, (1) pioneer communities, those fungi occurring during day $0-4$ and disappearing thereafter, (2) mature communities, those fungi occurring during an intermediate period of decay and disappearing thereafter, and (3) impoverished communities, those fungi occurring in the latter stages of decay and present until the end of the study. We identified 40 taxa from leaves of Berchemia, a climber growing on Magnolia liliifera trees. In a similar study at the same site, Promputtha et al. (2017) identified 23 taxa from Magnolia liliifera. Only four species (10\%), Beltrania rhombica, Colletotrichum gloeosporioides, Cylindrocladium floridanum, and Phyllosticta capitaliensis, colonizing leaves of Berchemia floribunda, overlapped with the fungi on leaves of Magnolia liliifera.

In previous leaf litter fungal succession studies, Parungao et al. (2002) examined ten leaves from different tree species in rainforests in northern Queensland, Australia and found between 0-14 taxa on each leaf species. Photita et al. (2001) examined the large leaves of Musa acuminata in Hong Kong and found 20 taxa on the leaves at Nim Shue Wan and 18 taxa on the leaves in Fung Yuen. In Thailand, Photita et al. (2003) recorded between 17 and 27 taxa on Musa acuminata leaves at various sites. Polishook et al. (1996) identified between 8 and 15 species from leaves of Manilkara bidentata and 9 and 11 species from leaves of Guarea guidonia in Puerto Rico. Nine taxa occurred on decomposing leaves, two species on freshly fallen leaves and four species on senescent leaves of Fagus crenata (Osono 2002). Promputtha et al. (2002, 2017) recorded 22 taxa on Manglietia garrettii and 23 taxa on Magnolia liliifera leaves. Forty-one taxa were found on leaves of the palm Nypa fruticans (Hyde \& Alias 2000). Appreciably greater numbers of fungi have been identified using indirect methods (pulverization-washing-plating of particle suspensions) to detect fungal diversity in litter (e.g. Polishook et al. 1996, Paulus et al. 2003).

\section{Time of substrate decomposition on high diversity}

Fungal diversity was high on leaves of Berchemia floribunda between day 4-16, with most species present on day 4 (Table 2). The time for fungal communities to reach a peak of species diversity, or fungal activity therefore varied between different studies. For example, complete decomposition of sugarcane bagasse needed 20 weeks and maximum colony counts were recorded during weeks 6-13 (Sandhu \& Sidhu 1980). In a 2-year study of the decomposition of leaf and root litter of pineapple, the number of species, the number of viable propagules associated with the litter and the rate of weight loss were maximum during the middle phase of the litter decomposition (Tiwari et al. 1994). During one year of complete decomposition process of fronds of Phoenix hanceana (120 days for leaves, 150 days for rachis tips and 200 days for mid-rachides and rachisbases), species diversity also peaked at the middle stage of decomposition (Yanna et al. 2002). The time taken for decomposition of leaf litter varies enormously, for example, 10 years to full decomposition of pine needles and one year for leaves in ash and sycamore woods (Tokumasu \& Aoiki 2002); a few weeks for tropical forest leaves (Hudson 1980); 14 months for leaves of sugarcane (Hudson 1962); 19 months for stems of couch grass (Hudson \& Webster 1958); two years for litter of pineapple (Tiwari et al. 1994); one year for leaves and rachis-tips of Phoenix hanceana and 18 months for mid-rachides and rachis-bases of Phoenix hanceana (Yanna et al. 2001).

\section{Fungal diversity on sterile leaves}

The saprobic fungi detected on sterilized leaves of $B$. floribunda were similar to those fungi found on non-sterilized leaves, although the numbers of fungal species on sterilized leaves was lower. Fryar et al. (2001) investigated the effect of autoclaving on the colonization pattern of fungi and found that the number of fungal species colonizing non-autoclaved wood was higher than on autoclaved wood. The overlap of fungi occurring on non-sterilized and sterilized leaves may result from the fungi being host-specific (Zhou \& Hyde 2001). The chemical content of leaves may effect germination or growth of specific fungal species resulting on re-occurrence of specific fungal taxa 
on the sterilized leaves. The reasons as to why saprobic fungi may occur recurrently on certain hosts is unclear, but may be related to the presence of these fungi as endophytes (Photita 2003, Promputtha et al. 2007, 2010, Jeewon et al. 2013, 2017, 2018), although the fact that similar fungi occur on the sterilized leaves places doubt on this.

\section{Effect of leaf bait condition on the diversity of fungi}

We also wanted to verify whether a leaf suspended above the ground had a different fungal community developing on it as compared to a leaf placed on the ground, either under the host tree or under another tree species in close proximity. This would possibly indicate whether the leaf litter fungi originate from the soil, colonize the leaves through aerial dispersal or are present in the leaves at senescence. In the latter case, they most likely are endophytes that become saprobes. Fungal communities on all baited groups were similar; the dominant species and the times of their occurrence were also similar. The results indicate that baiting leaves in different conditions had no effect on the diversity of fungi. The fact that leaves placed on the forest floor are similar to those hung in the tree canopy would suggest that the saprobes do not colonize through soil contact. The fact the leaves hung under different trees are similar also suggest that saprobes are not aerially dispersed, unless chemical components within the leaf control which saprobes can grow on an individual leaf. The results therefore indicate that saprobes may have been derived from endophytes within the leaves as suggested by Wong \& Hyde (2001), Ghimire \& Hyde (2004), Hyde et al. (2007) and Promputtha et al. (2007, 2010).

\section{Fungal communities on baits versus those on naturally decaying samples}

Examination of fungi on naturally occurring samples is likely to result in finding fungi that only occur during certain stages of decay. For instance, in this study fungal communities on naturally occurring decaying leaves were similar to those found on mature community stage of leaf baits (Tables 1, 2). Fungal communities which change rapidly, or taxa that are present for a relatively short time, may easily be missed on collections of naturally occurring samples, especially those that appear only during the pioneer or impoverished stages. For instance, Gliocladium sp. 2 on leaves of Magnolia liliifera was dominant (occurrence up to 60\%) for a short period only during the early succession study. It was not dominant on the naturally occurring sample. In addition, Dokmaia monthadangii on Magnolia liliifera was dominant (occurrence up to $11 \%$ ) on naturally occurring leaves, but was not found on the leaf baits (Table 2). The percentage similarities between fungi on naturally occurring samples and on the succession baits of Magnolia liliifera, Meliosma simplicifolia and Berchemia floribunda were high at $77 \%, 88.9 \%$ and $66.7 \%$, respectively. This study has demonstrated that examination of naturally occurring samples and leaf baits from initial senescence to complete decomposition are essential to obtain a full understanding of the fungal diversity on leaves of Magnolia liliifera, Meliosma simplicifolia and Berchemia floribunda.

\section{Factors supporting higher diversity}

The reasons for higher diversity of fungi in this study compared to some previous studies are unclear. Large leaves, with a greater surface area may provide more substrata for fungal growth and thus support a larger number of species (Promputtha et al. 2002). Photita et al. (2001) reported that the large leaves of Musa acuminata supported a higher diversity than the smaller leaves of other tree species. The three-tree species studied had different sized leaves. In the case of Berchemia floribunda, the decaying period is only 24 days, but still more species were obtained than from some longer decaying periods (Polishook et al. 1996, Osono 2002).

\section{Acknowledgements}

Partial funds for this research were provided by Chiang Mai University. K.D. Hyde thanks The Institute of Science and Technology Development of Chiang Mai University for funds to visit Chiang Mai University. Rampai Kodsueb is thanked for sample collections. W.H. Ho is thanked for 
help with statistics. Danushka Tennakoon would like to thank Prof. Chang-Hsin Kuo and Prof. TK Goh for their valuable suggestions and help.

\section{References}

Chomnunti P, Hongsanan S, Hudson BA, Tian Q et al. 2014 - The Sooty Moulds. Fungal Diversity $66,1-36$.

Dix NJ, Webster J. 1985 - Fungal Ecology. Chapman and Hall, London.

Frankland JC. 1966 - Succession of fungi on decaying petioles of Pteridium aquilinum. Journal of Ecology 54, 41-63.

Fryar SC, Tsui KM, Hodgkiss IJ, Hyde KD. 2001 - The influence of competition between tropical fungi on wood colonization in streams. Microbial Ecology 41, 245-251.

Gao C, Montoya L, Xu L, Madera M et al. 2019 - Strong succession in arbuscular mycorrhizal fungal communities. The ISME journal 13, 214-226.

Ghawana VK, Shrivastava JN, Kushwaha RKS. 1997 - Some observations on fungal succession during decomposition of wool in soil. Mycoscience 38, 79-81.

Ghimire SR, Hyde KD. 2004 - Fungal endophytes, in: Varma, A., Abbott, L., Werner, D., Hampp, R. (Eds.), Plant surface microbiology. Springer, Berlin, 281-292.

Gorska B. 1982 - Changes of microfungi during decomposition of plant material in two different woodland associations. Prace Naukowe Uniwersytetu Slaskiego Katowicach, 99-119.

Handa T, Harada Y. 2005 - Succession of microfungal flora on Rodgersia podophylla plants at the forest side of Cryptomeria plantation. Mycoscience 46, 129-136.

Herzog C, Hartmann M, Frey B, Stierli B et al. 2019 - Microbial succession on decomposing root litter in a drought-prone Scots pine forest. The ISME journal 13, 2346-2362.

Ho WH, Yanna, Hyde KD, Hodgkiss IJ. 2002 - Seasonality and sequential of fungi on wood submerged in Tai Po Kau Forest Stream, Hong Kong. Fungal Diversity 10, 21-43.

Hudson HJ. 1962 - Succession of micro-fungi on aging leaves of Saccharum officinarum. Transactions of the British Mycological Society 45, 395-423.

Hudson HJ. 1980 - Fungal Saprophytism. The Camelot Press Ltd., London.

Hudson HJ, Webster J. 1958 - Succession of fungi on decaying stems of Agropyron repens. Transactions of the British Mycological Society 41, 165-177.

Hyde KD, Alias SA. 2000 - Biodiversity and distribution of fungi associated with decomposing Nypa fruticans. Biodiversity \& Conservation 9, 393-402.

Hyde KD, Bussaban B, Paulus B, Crous PW et al. 2007 - Biodiversity of saprobic fungi. Biodiversity \& Conservation 16, 17-35.

Jeewon R, Ittoo J, Mahadeb D, Jaufeerally-Fakim Y et al. 2013 - DNA based identification and phylogenetic characterisation of endophytic and saprobic fungi from Antidesma madagascariense, a medicinal plant in Mauritius. Journal of Mycology 13, ID 781914.

Jeewon R, Wanasinghe DN, Rampadaruth S, Puchooa D et al. 2017 - Nomenclatural and identification pitfalls of endophytic mycota based on DNA sequence analyses of ribosomal and protein genes phylogenetic markers: A taxonomic dead end? Mycosphere 8, 1802-1817

Jeewon R, Yeung, QSY, Wannasinghe DN, Rampadaruth S et al. 2018 - Hidden mycota of pine needles: Molecular signatures from PCR-DGGE and Ribosomal DNA phylogenetic characterization of novel phylotypes. Scientific Reports 8, 18053

Jones EBG, Hyde KD. 2002 - Succession: where do we go from here? Fungal Diversity 10, 241253.

Kane DF, Tam WY, Jones EBG. 2002 - Fungi colonising and sporulating on submerged wood in The River Severn, UK. Fungal Diversity 10, 45-55.

Kodsueb R, Lumyong S, McKenzie EHC, Bahkali AH, Hyde KD. 2015 - Relationships between terrestrial and freshwater lignicolous fungi. Fungal Ecology 19, 155-168. 
Leung SS. 1998 - A study of saprophutic fungi associated with bamboo culms in terrestrial, freshwater and marine habitats, Ph.D. Thesis, The City University of Hong Kong, Hong Kong.

Matsuoka S, Suzuki Y, Hobara S, Osono T. 2018 - Fungal succession and decomposition of composted aquatic plants applied to soil. Fungal ecology 35, 34-41.

McMullan-Fisher SJM, May TW, Keane PJ. 2002 - The macrofungal community and fire in a Mountain Ash forest in southern Australia. Fungal Diversity 10, 57-76.

Newman MM, Liles MR, Feminella JW. 2015 - Litter breakdown and microbial succession on two submerged leaf species in a small forested stream. PloS one 10, p.e0130801.

Osono T. 2002 - Phyllosphere fungi on leaf litter of Fagus crenata: occurrence, colonization, and succession. Canadian Journal of Botany 80, 460-469.

Parungao MM, Fryar SC, Hyde KD. 2002 - Diversity of fungi on rainforest litter in north Queensland, Australia. Biodiversity \& Conservation 11, 1185-1194.

Paulus B, Gadek P, Hyde KD. 2003 - Estimation of microfungal diversity in tropical rainforest leaf litter using particle filtration: the effects of leaf storage and surface treatment. Mycological Research 107, 748-756.

Paulus B, Gadek P, Hyde KD. 2006 - Successional patterns of microfungi in fallen leaves of Ficus pleurocarpa (Moraceae) in an Australian tropical rainforest. Biotropica 38, 42-51.

Photita W. 2003 - Survey and isolation of endophytic and saprobic fungi of wild banana in Doi Suthep-Pui National Park, Ph.D. Thesis, Chiang Mai University, Chiang Mai, Thailand.

Photita W, Lumyong S, Lumyong P, Ho WH et al. 2001 - Fungi on Musa acuminata in Hong Kong. Fungal Diversity 6, 99-106.

Photita W, Lumyong S, Lumyong P, McKenzie EHC, Hyde KD. 2003 - Saprobic fungi on dead wild banana. Mycotaxon 85, 345-356.

Polishook JD, Bills GF, Lodge DJ. 1996 - Microfungi from decaying leaves of two rainforest trees in Puerto Rico. Journal of Industrial Microbiology 17, 284-294.

Promputtha I, Lumyong S, Lumyong P, McKenzie EHC, Hyde KD. 2002 - Fungal succession on senescent leaves of Manglietia garrettii in Doi Suthep-Pui National park, northern Thailand. Fungal Diversity 10, 89-100.

Promputtha I, Lumyong S, Dhanasekaran V, McKenzie EHC et al. 2007- A phylogenetic evaluation of whether endophytes become saprotrophs at host senescence. Microbial Ecology 53, 579-590.

Promputtha I, Hyde KD, McKenzie EHC, Peberdy JF, Lumyong S. 2010. Can leaf degrading enzymes provide evidence that endophytic fungi becoming saprobes?. Fungal Diversity 41, 89-99.

Promputtha I, Mckenzie EH, Tennakoon DS, Lumyong S, Hyde KD 2017 - Succession and natural occurrence of saprobic fungi on leaves of Magnolia liliifera in a tropical forest. Cryptogamie Mycologie 38, 213-226.

Richardson MJ. 2002 - The coprophilous succession. Fungal Diversity 10, 101-111.

Richardson MS. 2001 - Diversity occurrence of coprophilous fungi. Mycological Research 105, $387-402$.

Sandhu DK, Sidhu MS. 1980 - Fungal succession on decomposing sugarcane bagasse. Transactions of the British Mycological Society 75, 281-286.

Sivichai S, Jones EBG, Hywel-Jones NL. 2002 - Fungal colonisation of wood in a fresh water stream at Tad Ta Phu, Khao Yai National Park, Thailand. Fungal Diversity 10, 113-129.

Shi L, Dossa GG, Paudel E, Zang H et al. 2019 - Changes in fungal communities across a forest disturbance gradient. Applied and environmental microbiology 85, pp.e00080-19.

Somrithipol S, Jones EBG, Hywel-Jones NL. 2002 - Fungal diversity and succession on pods of Delonix regia (Leguminosae) exposed in a tropical forest in Thailand. Fungal Diversity 10, 131-139.

Suzuki A, Uchida M, Kita Y. 2002 - Experimental analyses of successive occurrence of ammonia fungi in the field. Fungal Diversity 10, 141-165. 
Tang AMC, Jeewon R, Hyde KD. 2005 - Successional patterns of microfungi in fallen leaves of Castanopsis fissa (Fagaceae) in Hong Kong forest. Canadian Journal of Microbiology 51, 967-974.

Tiwari SC, Tiwari BK, Mishra RR. 1994 - Succession of microfungi associated with the decomposing litters of pineapple (Ananas comosus). Pedobiologia 38, 185-192.

Tokumasu S, Aoiki T. 2002 - A new approach to studying microfungal succession on decaying pine needles in an oceanic subtropical region in Japan. Fungal Diversity 10, 167-183.

Tribe HT. 1957 - Ecology of micro-organisms in soils as observed during their development upon buried cellulose film, in: Williams, R.E.O., Spocer, C.C. (Eds.), Microbial Ecology. Cambridge University Press, Cambridge, 287-298.

Tribe HT. 1961 - Microbiology of cellulose decomposition in soil. Soil Science 92, 61-77.

Voříšková J, Baldrian P. 2013 - Fungal community on decomposing leaf litter undergoes rapid successional changes. The ISME journal 7, 477-486.

Wong MKM, Hyde KD. 2001 - Diversity of fungi on six grasses species of Gramineae and one species of Cyperaceae in Hong Kong. Mycological Research 105, 1485-1491.

Yanna, Ho WH, Hyde KD. 2002 - Fungal succession on fronds of Phoenix hanceana in Kong Kong. Fungal Diversity 10, 185-211.

Yanna, Ho WH, Hyde KD, Goh TK. 2001 - Occurrence of fungi on tissues of Livistona chinensis. Fungal Diversity 6, 167-180.

Zhang Y, Ni J, Tang F, Jiang L et al. 2017 - Diversity of root-associated fungi of Vaccinium mandarinorum along a human disturbance gradient in subtropical forests, China. Journal of Plant Ecology 10, 56-66.

Zhou DQ, Hyde KD. 2001 - Host-specificity, host-exclusivity and host-recurrence in saprobic fungi. Mycological Research 105, 1449-1457.

Zhou DQ, Hyde KD. 2002 - Fungal succession on bamboo in Kong Kong. Fungal Diversity 10, 213-227. 